\title{
School Housewife: Woman's Empowerment Model by Utilizing Skills and Local Natural Resources in Batu Town, East Java, Indonesia
}

\author{
Ishomuddin* \\ Professor Dr., Faculty of Islamic Education, University of Muhammadiyah Malang, Indonesia \\ *Corresponding Author: Ishomuddin, Professor Dr., Faculty of Islamic Education, University of \\ Muhammadiyah Malang, Indonesia
}

\begin{abstract}
The purpose of this study is to describe the models of empowerment of poor women in sub-urban area and the forms of urban poor women's empowerment done by institutions or non-governmental organization. By using a qualitative approach, this research was conducted in Batu Town by taking two focus community activities undertaken in an effort to empower women. The conclusion of this study is that the efforts are in the forms of (1) school of housewife. The school is attended mostly women who had been married date to be skills-based natural environment. The result is a very supportive family economy, (2) Aisyiyah skilled house. This community is in the form of one of the programs carried out by the branch of Muhammadiyah Batu town. As the women' schools, women's empowerment is to have focus on developing skills of women who are married armed with skills to cultivate the existing natural resources. With this activity greatly helped the family economy.
\end{abstract}

Keywords: Batu Town, Empowerment, Local Nature, School Housewife, Skilled Human

\section{INTRODUCTION}

If we observe the social reality of Indonesia, much more if we focus on the lives of women, surely we would find is a concern. Why does the position of women is not profitable? Indeed, on the one hand we can say that social reality is not favorable for women is related to overly dominant patriarchal culture. Therefore, the fight against social injustice in the history of humanity in the conception of community is important. This is as it is said that "one approach that is now frequently used in improving the quality of life and uplift the dignity of women is the empowerment of women" (Kartasasmita, 1995). The reality of injustice to women ranging from marginalization, such as speech and treatments: "God's creatures number two, half the price of a boy, as a helper, dependent on men, and often treated harshly or half slave. As if to position women as second-class citizens, which impact on the reduction of rights" (Tan, 1995).

One approach that is now often used to improve the quality of life and raise the dignity of women in the empowerment of women. The concept of empowerment of women is very important because it provides a positive perspective towards women. So that "women in reaching the reality of life is not seen as being underprivileged" (Suhendra, 2006); (Muttalib, 1993). Conceptually, empowerment comes from the word "power" which means empowerment or power. Empowerment is a means by which "a person, people, organization. and community directed to be able to master (power over) life" (Suharto, 2003); (Widjaja, 2003). Empowerment is a process by which people become strong enough to participate in a wide range of control over, and influence on the events and institutions that affect their lives.

Community development paradigm that emerged as a central issue of development today came in response to the fact the gap unresolved resolved, especially among people in rural areas, remote areas and backward. Whereas national economic growth in urban areas continues to increase. Therefore "empowerment basically puts the community as well as the center of attention and main development actors (people-centered development)" (Fakih, 2005). Development programs in the 1990s that started from the IDT program (Instruction Villages) have demonstrated the government's determination to 
alleviate poverty and also as part of the embodiment of development alternatives that see the importance of human (society), no longer as an object, but the subject development. In this context "fully public participation" is regarded as a determinant of development success. In the conventional sense, the concept of empowerment contains two meanings, namely "(1) to give power or authority to or give power, transferring power, or delegate authority to another party, (2) to give ability to or to enable or attempt to give the ability or empowerment. Explicit in this second sense is how to create opportunities to actualize one's empowerment" (Wrihatnolo, R.R. \& Dwidjowijoto, 2007).

The implementation of the empowerment of the most widely used in poverty alleviation efforts. According to Rapport, "poverty reduction efforts conceptually can be done by four strategic lines, namely the expansion of opportunity, empowerment, capacity building, and social protection. Expansion strategy aimed at creating opportunities and environmental circumstances of the economic, political, and social that allow poor people, both men and women can obtain the widest possible opportunity in meeting basic needs and improving the quality of life in a sustainable manner" (Rappaport, 2001). Community empowerment strategies are made to strengthen the institutional, political, economic and cultural, and broaden the participation of poor people, both men and women in public decision-making that guarantees the respect, protection and fulfillment of basic needs. Capacity building strategy undertaken to develop fundamental skills and abilities sought the poor, both men and women to take advantage of the development environment. "Social protection strategy undertaken to provide protection and security for vulnerable groups (female heads of households, the poor, the elderly, abandoned children, different abilities/handicapped) and the poor is new both men and women that is caused partly by the disaster nature, the negative impact of the economic crisis, and social conditions" (Wrihatnolo, R.R. \& Dwidjowijoto, 2007).

Poverty reduction efforts in practice can take place in the following two variations. "First, the program adopted more than one of these strategies in parallel and are associated. For example, the District Development Program, the Urban Poverty Program, Community Empowerment Program Coastal and Small Islands, and Farmers Income Improvement Program and the Small Fishermen to run the instrument of community empowerment, capacity building, expansion of business opportunities, and social protection. Secondly, there is one program that is only adopt one of these strategies. In Indonesia, for example Direct Cash Assistance Program for Poor Households as an instrument of social protection strategy. Subsidy Reduction Compensation Program Fuel to poor households through an educational component (School Operational Assistance Program) and health (Health Insurance Program for Poor Families) to run the instrument capacity building strategy" (Wrihatnolo, R.R. \& Dwidjowijoto, 2007).

Economic globalization is influenced by neoclassical economics and the power of transnational capitalist has had an impact on many people. They feel that the mainstream economy no longer meets their needs. This is reflected in high unemployment in the community and coupled with the "hidden unemployed" are those that are not counted in the official statistics. They want to have a permanent job or are only working part time is not fixed and want a better job. therefore "the impact of globalization is also seen in the increasing number of poverty that is reflected not only in the statistics the poverty line, but also in a number dependence on emergency aid such as food aid, cash directly, barns and so on" (Martono, 2011). Worse still is the impact of industrial globalization on society as Ife said "the whole community can be economically marginalized, as an industry that is moving global market logic and "free trade" where all that remains is the lid factories, the loss of jobs, communities devastated and personal despair" (Ife, 2006).

From the perspective of the development community's response to the economic crisis aimed at developing an alternative approach that attempts to resettle the economic activity in the local community and improve the quality of life. According to Shragge "the ongoing economic crisis has forced many people and communities to seek alternatives. In reality, mainstream economics no longer function effectively to meet their needs, the interests of which culminated in community economic development" (Shragge, 2009). Community economic development can have different forms, but the forms can be grouped into two categories. "First, a more conservative approach seeks to develop economic activity in most of the conventional parameters. While the second category, a more radical approach, which seeks to develop community-based economic alternatives" (Ife, 2006). 
Community empowerment program launched by the government and NGOs do not always run smoothly. Often experienced problems especially empowerment programs conducted in communities that embraces the culture of patriarchy. The growing culture of patriarchy in society have brought asymmetric situation, inequality and subordinate against women. Women only seen as second-class people in many ways. Often the empowerment program was designed only for the men - only men, so that there is the potential of women can not be developed. This fact had been the problem to then find the right solution so that sustainable development can be achieved.

This study started from the problem as follows: How does the model empowering poor women in sub-urban areas through institutional and non-governmental organizations do? Second, how the forms of urban poor women's empowerment is done by institutions or non-governmental organizations? Departing from the problems mentioned above, the purpose of this study is to describe the model of empowerment of poor women in sub-urban areas through institutional and non-governmental organizations.

\section{LITERATURE REVIEW}

In the discourse of social work, the term empowerment is now a warm conversation in various circles is not something new. Social work as a profession has a nature that is on relief and services to individuals, families, groups, organizations, and community dysfunction. Based on that, actually since the beginning of the development of social work always using themes such as self-reliance, selfconfidence, social functioning, and empowerment.

Before discussing more about the empowerment it must first know what is meant powerlessness. Theorists such motivation as Martin said "helplessness and empowerment is strongly associated with motivation and learning. Therefore, they developed a theory called the theory of learned helplessness" (Martin, 1967). Relevant to it, empowerment comes from the translation in English of "empowerment" which also means "giving power" due to power not just "power", but also "power", so the word "power" not only means "capable", but also "have the power" (Wrihatnolo, R.R. \& Dwidjowijoto, 2007), Ife (1995) said empowerment aims to increase of the power of disadvantaged (empowerment aims to give power or authority to people who are not lucky). Swift \& Levin tend to define "empowerment as a major reallocation of power. The roots of the ideology of empowerment go deep into the political and philosophical foundations of this country. The concept of democracy and its embodiment in our political institutions are based on the principle of empowering citizens to participate indecisions affecting their welfare" (Swift \& Levin, 1987). Rapport in Swift \& Levin said that "the concept suggests both individual determination over one's own life, and democratic participation in the life of one's community, often through mediating structures such as schools, neighborhoods, churches, and other voluntary organizations. Empowerment conveys both a psychological sense of personal control or influence, and a concern with actual social influence, political and legal rights. It is a multilevel concept applicable to individual citizens as well as to organizations and neighborhoods; it suggests the study of people in context" (Swift \& Levin, 1987). So, "empowerment as a way in which people, organizations, and community directed in order to rule over life" (Fahrudin, 1968).

Empowerment in the context of society is the ability of individuals who fused in the community and build community empowerment is concerned. Communities that most members were physically and mentally healthy, educated and strong and innovative, certainly has a high empowerment. However, in addition to the physical value, some intrinsic value in a society that is also a source of empowerment such as kinship, mutual cooperation, effort, and that is typical of the people of Indonesia, namely diversity. As in so many communities Batu Town that has so much local knowledge so that it can be authorized in community empowerment activities. In other words, is to enable and empower the community's independence. Empowerment is a "process of becoming" not an "instant process". As a process, empowerment has three phases, namely, awareness, provision of capacity and deception. It can simply be explained as follows.

The first stage is awareness. At this stage targets to be powered by "enlightenment" in the form of awareness that they have the right to have "something". For example, the target is the poor. They are given the understanding that they could be located, and it can be done if they have the capacity to get 
out of poverty. The programs can be done at this stage such as providing knowledge that is cognition, belief, and healing. The basic principle is to make the target to understand that they need to (build the "demand") are empowered and empowering process starts from within themselves (not from others).

The second stage is providing capacity. This is often referred to capacity building, or in simpler language enabled or enabling. To be given the power or authority, the concerned should be able to advance. For example, before giving regional autonomy, should the areas to be dichotomy by empowerment or capacity building program to make them "competent" (skilfull) manage the autonomy given. Capacity building process consists of three types, namely human, organization, and value systems. The third stage is the provision of power itself - or empowerment in the narrower sense. At this stage, the target is given power, power, authority, or opportunities. This Award in accordance with the quality of the skills that you already have.

\section{METHODOLOGY}

This research is field research and focus on the paradigm that syntesyze both macro and micro paradigm (macro-micro link). As in Sociology, those paradigm shows that reality developed in the relational process between agent and structure. Agent in this research is the subject and the structure is the culture values in the Indonesian. While the methods that will implement in this research described as follows:

\subsection{Research Location}

The research was conducted in Batu Town. The reason of this locations, is that the location has local value potential that can be analysed as the factors that gives description of the local culture in the people's daily life.

\subsection{Subject of Research}

The subject of the research is women who actively participate in empowerment through social institutions and non-governmental organizations.

\subsection{Data Collection}

In the data collection method, researcher use a common methods in qualitative research as Denzin dan Lincoln suggested in his book entitled Handbook of Qualitative. (Denzin Y.S. \& Lincoln, 2005); (Lincoln, Y.S. \& Guba, 1985).

\subsubsection{Observation}

Researcher takes direct observation in the location, following guidance that have already created as (1) the construction of model empowering poor women in urban areas through institutional and nongovernmental organizations do. (2) the construction of the forms of urban poor women's empowerment is done by institutions or non-governmental organizations.

\subsubsection{Indepth Interview}

The use of this method is for the data collection purposes as it analyses (1) the model of empowerment of poor women in urban areas through institutional and non-governmental organizations. (2) the forms of urban poor women's empowerment is done by institutions or nongovernmental organizations.

\subsubsection{Documentation}

This research needs some document data like archive or document about woman such as number of females and type of work. The number of women who participated in empowerment. in Batu Town.

\subsubsection{Focus Group Discussion (FGD)}

FGD according to Irwanto (Irwanto, 2006) is the process to collect data and systemic information about specific problem by group discussion. FGD is used by philosophical, methodological and practical reason. As philosophical reason, FGD gives information from many perspectives so it can enrich the research results. As metodhological reason is that if in the research, information it can be found in the other methods, so FGD is one of the options. And as practical reason is that the persons 
that involved in the FGD is not as "object" but as "subject" that active and free and feel involves in the result of the research.

In this FGD, it needs a team that contain of one moderator, one notulen, one participant relations, one blocker who anticipate the negative effect in FGD, one or one logistics that helps on accomocation and transportantion. In this research, the data collected in FGD is the data about the model and the forms of woman empowerment.

\subsubsection{Data Analyze Method}

The data that have been compilled by the observation, interview and documentation then analyzed with some steps as reduction, display, verification and conclusion (Miles, M.B., Huberman, 2014). In the reduction step, the data will be simplified, abstract and transforming the raw data from the field research. The data reduction will be done time by time in the research and even it starts before the researchers decide the conceptual framework of research area, research problem and approaches in data collection. Reduction also continues after field study in Batu Town.

Data display is groups of information compiled that possible to make conclusion. The display that often used is in the narrative text. In the beginning the text informations are broad, as well as interview with the subject, also the secondary data like archives and documents about women empowerment program. Then, researcher will simplify those complex information in the unity (gestalt) with configuration that easy to understand in the narrative way.

The verification and conclusion step is the part of one fixed configuration. The conclusion will be always verified so the principle of the analysis data is circular. All of the data analyses process can be described in the figure bellow:

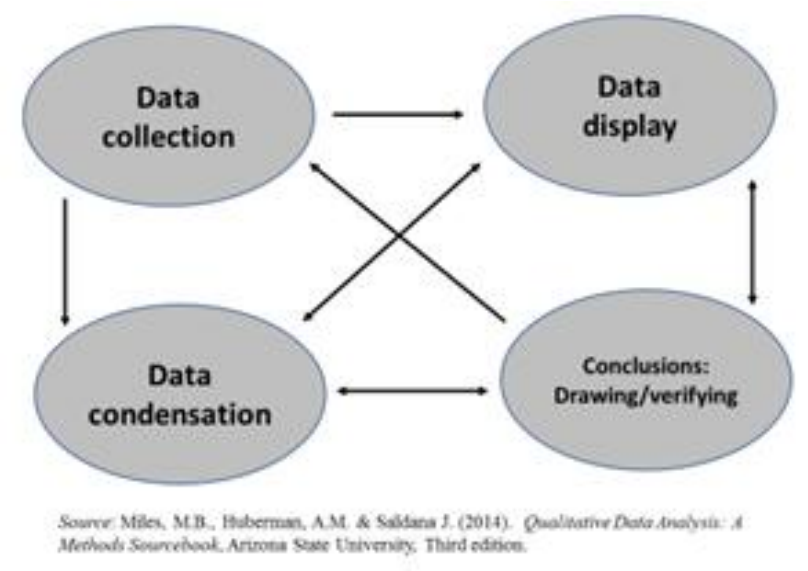

\subsubsection{Data Validity Method}

As in the quantitative research, the qualitative research also uses the procedure to evaluate the validity of the data that done in some steps as follows: (1) prolonging observation time; (2) triangulate sources by checks one source with others; (3) doing member check, is reconfirm data with the informant, (4) peer debriefing, (Janesick, 2007) is when researchers doing discussion with colleagues, especially expert in University of Muhammadiyah Malang who concern in study and women empowerment.

\section{FINDINGS}

\subsection{Aisyiyah Skilled House}

Rumah Terampil Aisyiyah (Aisyiyah Skilled House) starts their activities since 2011 which all of them based on Padang Makhsyar Mosque. Vision of this organization is facilitating and as mediator for women, mother, teenager, girl to become taqwa, healthy, independent, competitive and productive human. While the mission are taqwa, healthy, independent, competitive and productive. The organization was founded by The Branch of A'isyiyah of Bumiaji residence, the members, and women activist who concern in women empowerment. The member of the organizations are mother, teenager and girls in Batu town which are coordinated by branch of A'isyiyah and members by individual and groups. The member also as housewife, flower farmer, vegetable farmer, fruit farmer, 
worker, student and merchants. Aisyiyah Skilled House is one of A'isyiyah organization activity which dedicated to goodness for community and place to gather for moslem women to share the experiences, knowledge and fulfill their needs. The knowledge that they want to develop are related with knowledge and experience to improve productivity, economic, basic Islamic knowledge as mention in Al Quran and As Sunnah. Aisyiyah Skilled House also place for discussion, gather, open and independent sharing, unlimited time, space and number. The activity held based on agreement among member and committee as mediator and expert. The expert who give lesson to the member are experts in some fields like flowering, culinary, sewing, bonsai and moslem leader. The activities are divided into six chapters. They are religion, culinary, flowering, health, handycraft and service.

\subsection{School of Housewife}

School of Housewife was founded by Learning Center for Rural Women, while Learning Center for Rural Women is a school for women in the rural area. It is a place for rural women to share the knowledge and experience, fulfill their needs and interest, to improve their living quality. It aims to develop and strengthening women leadership in rural area. The knowledge and experience that be share in this school is related with both women practically and strategically needs. The practically needs are knowledge and skill to improve family income, culinary, culinary business, technology and information, gender equality, parenting knowledge, nutrition (healthy food), sanitation, women reproduction right, family health, English, public speaking and women leadership. While strategically needs are human right knowledge, children right, women right, minority right, civic education, local and national development plan and budged, global economic system which influences women life, women right of food (production, distribution, consumption system), sustainable agriculture, environment and climate change. The school was founded by Suara Perempuan Desa (Rural women's voices) and Karya Bunda Community in Batu town. In 2013 the number of participants are 275 from 4 villages. In 2014 the number become 135 from 5 villages. The expert as teacher for the school are individual and institution from Batu and outside. The school starts in 23 August 2013. The school implements feminism principles and adult education like participative method and women knowledge and experience as source of learning process. It is following some values like simple, independent, honest, fair, equality and togetherness, plurality, against violence and discrimination. The school helds in the first and third week every month from 1-3 pm. Every month they held monitoring and evaluation by focus group discussion with 10-15 members. The funding are self funding by members and also supported by some institutions which have similar vision.

\section{DisCUSSIONS}

From the results mentioned above, in the study, found a way that is done in empowering women is through non-formal education. Skills education by the community in the form of the School of Women. Second, education skills, conducted by socio-religious organization that is Muhammadiyah. The difference is, if the School of Housewife is to accommodate all women who are not constrained by the group, ethnicity, and religion, then A'isyiyah, restricting only transform Muhammadiyah members or participants. In religious organization like A'isyiyah the religious value is strongly supports the activities and also the motivation of member to join the program. Mosque as the basic or core of activities is playing important role. It is like the spiritual value on their activities as the activities are part of ibadah or praying or goodness for the God. It also influences in funding support where the motivation to funding the program is not only for material thing like activities, but also for sacresfy to the God. That's why in religious based organization, the funding relatively is not problem. In religious based organization, the motivations are both material and spiritual and spriritual value have important point.

Empowerment of women's education is still important than using other approaches. Because this approach can take advantage of social values, culture and other local values. The empowerment of women through education emphasis on the skills, knowledge, and power enough to affect their lives and the lives of others concerns. Empowerment refers to the capability, especially vulnerable groups, in order to have access to productive resources that enable them to improve their quality of life and can participate in the development process and the decisions that affect them. Given that education is a very important issue and fundamental to empower women, it is a must that the empowerment of women education was also conducted as a prerequisite for the empowerment of women themselves. 
The empowerment of women is a way of education or effort in order to improve and develop education for women. This can be done including:

- Providing greater opportunities to women to be able to follow or education as widely as possible. This is necessary given the strengthening of the community paradigm that the highest female education daughters will eventually be returned to the kitchen. This has resulted in the low (mostly) female education.

- Conducting campaigns and provide awareness to women about the importance of education and the equality of rights between men and women to get an education. To minimize abuseharassment or injustice suffered by women, it is very possible dissemination and awareness of the importance of education becomes a necessity.

- Conducting research on the participation of people, especially women in the empowerment and improvement of education for women. This activity is very urgent, as this will be the foundation for anyone who is campaigning for gender movement. This fact became a yardstick to determine the orientation of gender movement. When in place, the level of female education is minimal, then the various activities can be arranged to cover the shortfall.

- Preparing the steps in anticipation of the constraints and obstacles to be faced in the process of empowerment for women's education. This needs to be done because there is little evidence that encountered in the field, in contrast to expectations. So if you have no preparation on the anticipation of obstacles that will be encountered, any activity can be said to be running smoothly.

Development of educational empowerment of women do to support and accelerate the achievement of women's empowerment to the quality of life and partner alignment men and women engaged in the whole field or sector. The success of the development of educational empowerment of women into the ideals of everyone. But to find success as a process, it can be seen from the indicators of achievement of success. As for the educational empowerment indicators toward women are as follows:

- Their vehicle and adequate means and rules of law that support for women's education as much as possible.

- Increased participation and spirit of women for trying to acquire and receive education and instruction for themselves.

- Increasing the amount of the percentage of women in educational institutions, especially universities.

- Increased involvement of women activists in the campaign against female education empowerment. But over it all is the creation of a mindset and paradigm egalitarian. Women should also be actively involved in some activities that are in proportion. If this has been realized, the education of women really has empowered.

Are there problems in the family when women join the program? No, because there is gender equality consciousness and most of the women have self income because they are working. The husband usually understands and supports the activity while the wife can manage their time between family and activities. There are "time sharing" in the family as sharing and dividing time between husband and wife in the family. How husband or man perception about the women activities? There are positive perception and the man support women activities because they are realized that the activities give benefits to improve women knowledge and skills. How about income? Husband as leader in the family so the income mostly come from husband, so how if the income used to support the activities by the women or wife? It is based on agreement between husband and wife. Although the family income comes from husband, but the wife can separate or spend money to support the activities as their husband know it. And the husband is agree and no problem. In other hand, some women have their own job or as worker so they have their own money. Who are support the activities? Mostly they are self funding but sometimes government or other institution also supports. They also held some economic activities like selling cookies and other product where the profit also uses to support their activities. 


\section{Conclusions}

Aisyiyah Skilled House started their activities since 2011 were all based on Padang Makhsyar Mosque. The organization was founded by the Branch A'isyiyah of Bumiaji (the name of area), members, and activists with an interest in women's empowerment. Members of the organization are mothers, teenagers and girls in Batu coordinated by A'isyiyah branches and members by individuals and groups. Aisyiyah Skilled House is one activity A'isyiyah organization dedicated to the goodness for the community and a place to gather for Muslim women to share experiences, knowledge and meet their needs. The knowledge that they want to develop related knowledge and experience to improve productivity and economy.

School of Housewife is learning Center for women in rural areas. This is a place for women to share knowledge and experiences, meet their needs and interests, to improve their quality of life. It aims to develop and strengthen women's leadership in rural areas. Knowledge and experience into the share at school is associated with both women's practical and strategic needs. Practical needs is the knowledge and skills to improve family income, culinary, culinary business, technology and information, gender equality, parental knowledge, nutrition (healthy food), sanitation, female reproduction right, family health, English, public speaking and women's leadership. While the strategic need is the knowledge of human right, children right, the right woman, minority rights, civic education, plan local and national development and growing, global economic system that affects the lives of women, the right woman of food (production, distribution, system consumption), sustainable agriculture, the environment and climate change.

\section{REFERENCES}

[1] Denzin Y.S. \& Lincoln, Y. S. Handbook of Qualitative. NY: Sage Publication, 2005.

[2] Fahrudin.. "Communal System and Regional Development Discussed", by Sebic, 13 Oligarchic Trends in Yugoslav Economy Criticized, by Vladimir Veselica, 7 SERBO-CROATIAN, np, V.jesnik u Srl.ledu, 17 Jul 1968.

[3] Fakih, M. Analisis Gender dan Transformasi Sosial. Yogyakarta: Pustaka Pelajar, 2005.

[4] Ife, J. \& T. F. C. D. C.-B. A. in an A. of G. P. E. A. (2006). Community Development: Community-Based Alternatives in an Age of Globalisation. Australia: Pearson Education Australia, 2006.

[5] Irwanto. Focused Group Dicussion (FGD). Yogyakarta: Yayasan Obor, 2006.

[6] Janesick, V. J. (2007). Peer debriefing. Online, Retrieved, 20(3), 2010. https://doi.org/10.1111/b.9781405 124331. 2007.x

[7] Kartasasmita, G. Pemberdayaan Masyarakat Sebuah Tinjauan Administrasi Pidato Pengukuan Jabatan Guru Besar Dalam Ilmu Administrasi Pada Fakultas Ilmu Administrasi. Malang. Universitas Brawijaya. Malang: Fakultas Ilmu Administrasi Universitas Brawijaya, 1995.

[8] Lincoln, Y.S. \& Guba, E. Naturalistic Inquiry. Beverly Hills: Sage Publications. 1985.

[9] Martin, E. P. S. "Learned helplessness" first was used by Overmier and Seligman. (1967). (In a recent paper, Maier and Seligman. (1976). Extensively review work on learned helplessness in animals.) ... of learned helplessness in humans (Fosco \& Geer (1967).

[10] Martono, N. Sosiologi Perubahan Sosial: Perspektif Klasik, Modern, Posmodern, dan Poskolonial. Jakarta: Rajawali Press, 2011.

[11] Miles, M.B., Huberman, A. M. \& S. J. Qualitative Data Analysis; A Methods Sourcebook. Arizona: Arizona State University, 2014.

[12] Muttalib, J. Menggunakan Kerangka Kemampuan Wanita, dalam Moeljarto Tjokrowinoto, dkk. Bahan Pelatihan Jender dan Pembangunan. Kantor Menteri Negara UPW, 1993.

[13] Rappaport. Ecology and the Sacred. The University of Michigan.: Michigan, 2001.

[14] Shragge, E. Lessons for Community Organizing. Toronto: University of Toronto Press, 2009.

[15] Suharto, E. Pembangunan Kebijakan dan Kesejahteraan Sosial. Bandung: Mizan, 2003.

[16] Suhendra. Peranan Birokrasi dalam Pemberdayaan Masyarakat. Bandung: AlFabeta, 2006.

[17] Swift, C., \& Levin, G. "Empowerment: An emerging mental health technology". The Journal of Primary Prevention, 8(1-2), 71-94. https://doi.org/10.1007/BF01695019, 1987.

[18] Tan, M. G. Perempuan dan Pemberdayaan. Makalah dalam Kongres Ikatan Sosiologi Indonesia. Ujung Pandang: Ikatan Sosiologi Indonesia, 1995.

[19] Widjaja, H. A. Otonomi Desa Merupakan Otonomi Asli Bulat dan Utuh. Jakarta: PT. Raja Grafindo Persada, 2003. 
School Housewife: Woman's Empowerment Model by Utilizing Skills and Local Natural Resources in Batu Town, East Java, Indonesia

[20] Wrihatnolo, R.R. \& Dwidjowijoto, R. N. Manajemen Pemberdayaan, Jakarta: Jakarta: Elex Media Komputindo, 2007.

\section{AUTHOR'S BIOGRAPHY}

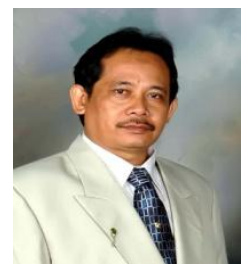

Professor Dr. Ishomuddin, M.Sc. Faculty of Islamic Education, University of Muhammadiyah Malang, Indonesia.

Citation: Ishomuddin. "School Housewife: Woman's Empowerment Model by Utilizing Skills and Local Natural Resources in Batu Town, East Java, Indonesia". International Journal of Humanities Social Sciences and Education (IJHSSE), vol 5, no. 7, 2018, pp. 64-72. doi: http://dx.doi.org/10.20431/2349-0381.0507008.

Copyright: (C) 2018 Authors. This is an open-access article distributed under the terms of the Creative Commons Attribution License, which permits unrestricted use, distribution, and reproduction in any medium, provided the original author and source are credited. 